\title{
巻頭言＼cjkstart庶務理事に就いて再認識したこと
}

\author{
小谷 明
}

\section{A Trivial Comment to the Polarographic Society of Japan}

\begin{abstract}
Akira Kotani
今現在、会誌の 59 巻 2 号の脱稿日が 迫っており、本部記事に加えて本稿を用 意しています。昨年、高尾での第58回ポー ラログラフィーおよび電気分析化学討論 会において大堺先生より巻頭言の執筆依 頼をいただきました。歴史ある本誌に私 のようなものは、非常におこがましい上 に、文才の無さも手伝って困っておりま した。改めて日本ポーラログラフ学会は どんなものかと会誌を開いてみると、い ろいろと本会の有難味を再認識しました。 駄文で恐縮ですが、その旨を記させてい ただきます。

さて、私にとって本会との初めての関 りは、1999 年に長崎で開催された第 45 回ポーラログラフィーおよび電気分析化 学討論会 (中嶋直敏 先生が世話人) で口 頭発表した折です。東京薬科大学の助手 として、社会人 1 年目でしたが、会期中 の講演と㭛親会を通じて、アットホーム な学会であることが、すぐに感じ取れま した。それ以降、2008 年には評議員とし て加えていただき、2013 年 1 月より庶務 理事を仰せつかって、現在に至っていま す。

現在、庶務理事になって 8 ケ月目、お かげさまで e-mail による 2 回目の理事会 も終わりました。小山先生の巻頭言に記

載のとおり（Rev. Polarogr., 54, 67 (2008)）、 本会の運営や会議は e-mailがほとんどで、 きちんとしたレールが敷かれています。 前任者の西先生より引き継ぎました約 $500 \mathrm{MB}$ もの歴代庶務ファイルを見ると、 システマティックに事業活動が行われて きたことがうかがえます。それらの助け を受けながら庶務理事の仕事を進めてい ます。本会の事業・運営等に直接的に関 わることができ、貴重な経験をしていま す。

e-mail は、コミュニケーション手段とし て大変便利であり、遠隔地であっても情 報を迅速に送ることができるメリットが あります。しかし、一般的なデメリット として、相手とリアルタイムで接触して いるわけではないので e-mail を相手に見 てもらうタイミングを送信者側はコント ロールできない、相手の様子は判らない ので誤解されることもある、などが挙げ られます。『目は口ほどにものを言う』 という諺ですが、これは科学的にも実証 されているようです。人類が進化の過程 で獲得した目の特徴である『強膜（白目） が広く露出し、大きな可動性のある眼球』 と『眼裂が非常に横長』は、他人とコミ ユニケーションを取るために重要な役割 を果たしているそうです。相手と顔を向
\end{abstract}


き合わせるコミュニケーションが如何に 不可欠であるかが判ります。

しかし、理事や幹事の先生方と e-mail で連絡する機会は毎月のようにあります が、上述のデメリットはあまり感じてい ません。これは、これまでに関連の先生 方と討論会等で気軽にお会いし、ざっく ばらんなお話ができ、人となりや䨌囲気 をイメージした上で e-mail の送受信がで きているからと考えています。樋上先生 が記した、本会の自由闊達な雾囲気 $(R e v$. Polarogr., 52, 155 (2006)）や楠先生が記し た、本会は暖かな人の輪がある（Rev. Polarogr., 55, 73 (2009)） というコメント に共感いたします。従って、e-mail を便利 に使う前提として、年に 1 度の討論会で 充分にお互いを知った上でコミュニケー ションをとることが重要と、考えるよう になりました。

学会は、自己の研究成果を発表してそ
の妥当性について他の研究者と科学的な 討論をする場、研究者同士の交流の場と して重要な役割を担いますが、個人的に は後者の方が大切ではないかと感じてい ます。幸いにも本会は、青木先生（Rev. Polarogr., 44, 103 (1998)） や西先生 (Rev. Polarogr., 57, 1 (2011)）よりご意見をいた だいている『討論』が充実していると思 います。討論と交流。これからも、この 両軸をしっかり維持することで本会は、 さらなる飛躍を遂げるのではないかと 思っています。

このような庶務理事ですが、巻頭言の 顔を知っていただくとコミュニケーショ ンが進むということで、駄文をお許しい ただきます。どうぞご指導ご鞭撻の程、 よろしくお願い申し上げます。

(こたにあきら・東京薬科大学薬学部、 本会庶務理事) 